\title{
First report of Rice orange leaf disease phytoplasma (16 SrI) in rice (Oryza sativa) in India
}

\author{
P. Valarmathi $\cdot$ R. Rabindran $\cdot$ R. Velazhahan $\cdot$ \\ S. Suresh • S. Robin
}

Received: 14 September 2013 / Accepted: 9 October 2013 / Published online: 26 October 2013

(C) Australasian Plant Pathology Society Inc. 2013

\begin{abstract}
Rice (Oryza sativa L.,) is one of the most important cereal crops worldwide. In this study, phytoplasmas have been detected in symptomatic leaves of four varieties of rice using nested-PCR with primer pairs P1/P7 and R16F2n/R16R2, which amplified a $1.2 \mathrm{~kb}$ fragment of the $16 \mathrm{~S}$ rRNA gene. The nucleotide sequence analysis of the fragment had $100 \%$ identity among the sequences from the four varieties (GenBank Accession numbers: JX290545, JX290546, JX290547 and JX290548) and $99 \%$ nucleotide sequence identity with 16S rRNA gene sequences of the Rice orange leaf disease phytoplasmas from the Philippines and Thailand, Maize bushy stunt phytoplasma and Wheat blue dwarf phytoplasma belonging to the 'Candidatus Phytoplasma asteris' (16SrI) group. This is the first report of $16 \mathrm{SrI}$ group phytoplasmas infecting rice in India.
\end{abstract}

Keywords Rice $\cdot$ Orange leaf phytoplasma $\cdot$ Nested PCR

Phytoplasmas are intracellular obligate prokaryotes that lack cell walls and have very small genomes $(680-1,600 \mathrm{~kb})$. Since the first report by Doi et al. (1967), phytoplasmas have been identified as pathogens in different plant genera and in some cases have caused severe epidemics in major crops such as grapevine, sugarcane and coconut (Weintraub and Beanland 2006). Phytoplasmas cause complex syndromes with symptoms

P. Valarmathi $(\bowtie) \cdot$ R. Rabindran $\cdot$ R. Velazhahan $\cdot$ S. Suresh $\cdot$

S. Robin

Department of Plant Pathology, Centre for Plant Protection Studies,

Tamil Nadu Agricultural University, Coimbatore 641 003, Tamil Nadu, India

e-mail: valarpath@gmail.com

P. Valarmathi $\cdot$ R. Rabindran $\cdot$ R. Velazhahan $\cdot$ S. Suresh $\cdot$ S. Robin Department of Rice, Centre for Plant Breeding and Genetics, Tamil Nadu Agricultural University, Coimbatore 641 003, Tamil Nadu, India such as stunting, proliferating auxiliary shoots, forming sterile deformed flowers, virescence, and phyllody in several hundred plant species (Lee et al. 2000). Based on phylogenetic analysis of gene sequences (16S rRNA) phytoplasmas were recently assigned to a provisional genus, 'Candidatus (Ca.) Phytoplasma' within the class Mollicutes (IRPCM 2004). The aster yellows (AY) phytoplasma group (16SrI) comprises AY and numerous related phytoplasmas that are associated with more than 100 economically important diseases worldwide, representing the most diverse phytoplasma group (Lee et al. 2004)

The Gramineae have the largest number of species associated with phytoplasma diseases worldwide, and are also the plant family where the majority of phytoplasma vector species (Delphacidae) have been found. Rice yellow dwarf (RYD) and Rice orange leaf (ROL) are the two phytoplasma disease that have been reported to infect rice. RYD, a serious problem for rice farmers, has only been detected to date in Asia, where it has been recorded from most rice-growing countries (Nakashima et al. 1993). Infected rice turns pale yellow and gradually starts to decay and produce numerous tillers. ROL has also only been found in Asia to date and the symptoms are typified by orange-coloured leaves, which later roll inward and desiccate. Despite the fact that infected plants die 2-3 weeks after the symptoms appear, diseased plants are generally distributed sporadically in the field so the disease does not as yet cause serious yield losses (Hibino et al. 1987). Phytoplasma have been associated with ROL in Thailand, Malaysia, Indonesia and the Philippines based on electron microscopy evidence (Hibino et al. 1987). Based on the 16S rDNA sequence similarity between ROL from the Philippines and Onion Yellows (OY) (99.9\%), along with other aster yellows subgroup members (98.9-99.8 \%), it is reasonable to classify the ROL phytoplasma in the AY $16 \mathrm{SrI}$ group, thus distinguishing it from RYD, which belongs to the 16SrXI group (Jung et al. 2002). 
The occurrence of orange leaf phytoplasmas in India has not previously been reported. However, recently the occurrence of phytoplasmas in the Cauvery Delta areas and other rice growing areas were noticed for first time. An extensive survey has been conducted in the Cauvery Delta, Lower Bhavani project Delta, Parambikulam Aliyar Delta, Periyar Vaigai Project Delta and Thamiraparani Delta zones. The plants exhibited typical symptoms with orange yellow discoloured leaves which were distributed sporadically in the field (Fig. 1). The symptoms were suspected to be phytoplasma as testing for Rice Tungro Disease (RTD) with PCR gave negative results and the bacterial blight pathogen could not be isolated. Subsequently we attempted to identify the causal agent by using nested PCR using phytoplasma specific primers.

Leaf samples were collected from four symptomatic plants of each of the rice varieties ADT 43, CO 39 and White Ponni (collected from TNAU farms, Coimbatore district) and BPT 5204 (from the Erode district) and used for the present study. A modified CTAB method (Warokka et al. 2006) was used for the extraction of total DNA from leaf samples of rice for detecting phytoplasmas. Nested-PCR assays with the universal primer pair P1/P7 followed by the universal primer pair R16F2/R2, designed to amplify a portion of the 16S rRNA gene (Lee et al. 1993; Gundersen and Lee 1996) were employed. One microlitre of DNA was used for first round amplification with primer pair $\mathrm{P} 1 / \mathrm{P} 7$ and $0.5 \mu \mathrm{l}$ of first round product was used as template in nested-PCR without dilution with phytoplasma specific primers R16F2n/R16R2. A total of 35 thermal cycles were carried out which included denaturation for $1 \mathrm{~min}(2 \mathrm{~min}$ for first cycle) at $94{ }^{\circ} \mathrm{C}$, annealing for $2 \mathrm{~min}$ at $50{ }^{\circ} \mathrm{C}$ and extension for $3 \mathrm{~min}\left(10 \mathrm{~min}\right.$ in final cycle) at $72{ }^{\circ} \mathrm{C}$. DNA fragments ca. $1.2 \mathrm{~kb}$ in size were amplified by nested-PCR (Fig. 2) from DNA extracts of symptomatic leaves from the infected plants but not from the DNA of healthy leaves. The nested-PCR was repeated thrice using the same samples. The DNA fragments were gel purified using a gel extraction kit (Qiagen, New Delhi, India) and cloned in plasmid (pGEMT ${ }^{\circledR}$ vector- Promega). The Plasmid DNA was directly sequenced in both orientations at SciGenom Labs Pvt Ltd, Kerala, India and

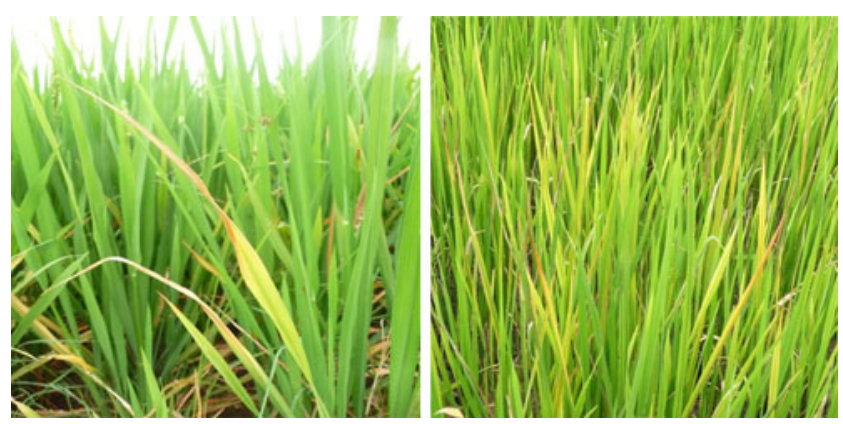

Fig. 1 Symptoms of Rice orange leaf (ROL) phytoplasma showing rolling of infected leaves towards the inner side (left) and typical orange coloured leaves (right)

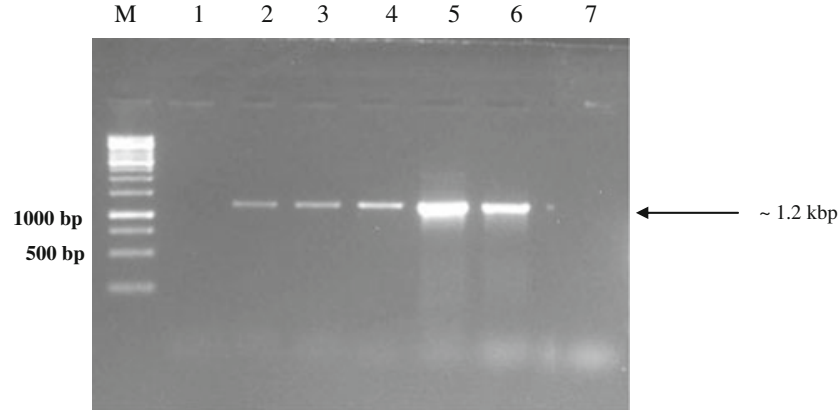

Fig. 2 Detection of phytoplasma through nested PCR using primers - P1/ P7 and R16F2n/R16R2. Lanes M - 1 kbp DNA ladder; (1) Negative control (Healthy rice sample); (2) Rice (Erode- BPT 5204): (3) Rice (Coimbatore-White ponni): (4) Rice (Coimbatore- CO 39); (5) Rice (Coimbatore- ADT 43); (6) Positive control (Infected brinjal); (7) Non template control

the subsequent $1,179 \mathrm{bp}$ of the sequence were aligned with Clustal W (Thompson et al. 1994). The NCBI BLAST program was used to scan the sequence data against other phytoplasma 16S rRNA gene sequences. A phylogenetic tree was constructed by the neighbour joining method using the MEGA software version 5 (Saitou and Nei 1987; Tamura et al. 2011).

The 1179-bp nucleotide sequences had $100 \%$ identity among the sequences from the four varieties (JX290545, JX290546, JX290547 and JX290548) and $99 \%$ nucleotide sequence identity with 16S rRNA gene sequences of 16SrI ('Candidatus phytoplasma asteris') phytoplasmas infecting the graminae family including rice orange leaf phytoplasma from the

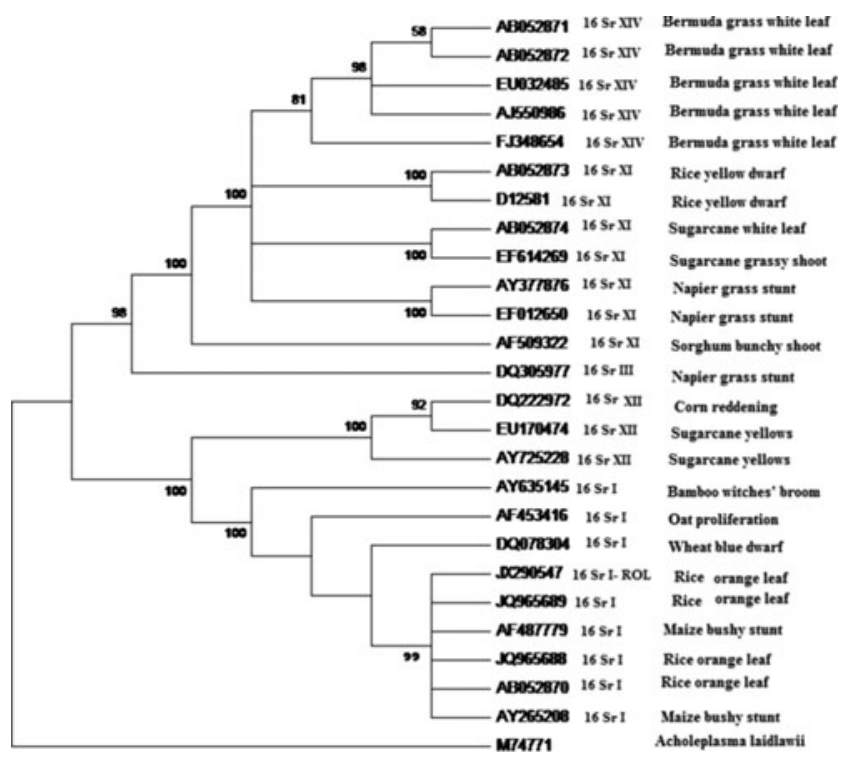

Fig. 3 Dendrogram constructed by the Neighbor-joining method, showing the phylogenetic relationships between the Rice orange leaf phytoplasma with different groups of phytoplasmas constructed based on 16S rRNA sequences. The numbers refer to the GenBank Accession numbers. For the ROL sequences, JX290547 is a sequence from India (this study), AB052870 from the Philippines, and JQ965688 and JQ965689 are from Thailand 
Philippines (AB052870), Maize bushy stunt phytoplasma (AY265208), Oat proliferation phytoplasma (AF 453416) and Wheat blue dwarf phytoplasma (DQ078304) (Fig. 3)

There are previous reports of phytoplasmas belonging to the ' $\mathrm{Ca}$. Phytoplasma asteris' $16 \mathrm{SrI}$ group in India including, Crotalaria witches' broom phytoplasma (FJ 185141) (Baiswar et al. 2010), Chrysanthemum little leaf (DQ 431842) (Raj et al. 2007), Chilli phytoplasma (DQ 343288) (Khan and Raj 2006) and Black pepper phytoplasma (FJ 462798) (Adkar-Purushothama et al. 2009). First reports of Sesame phyllody (DQ 431843) and Pigeon pea little leaf disease (DQ 343287) caused by phytoplasmas belonging to the aster yellow group have also been reported from India (Khan et al. 2007; Raj et al. 2006).

The symptom analysis and phylogenetic analysis in this study has confirmed the presence of Rice orange leaf phytoplasma (ROL) in India. As the 16S rDNA sequence similarity is greater than $97.5 \%$, the ROL phytoplasma clearly belongs to the $16 \mathrm{SrI}$ ' $\mathrm{Ca}$. Phytoplasma asteris' group as ROLassociated phytoplasmas from the Philippines and Thailand. 'Candidatus Phytoplasma asteris' group phytoplasmas have been reported in many crops in India, but to our knowledge, this is the first report of $16 \mathrm{SrI}$ aster yellows group phytoplasma infection of rice (Oryza sativa L.,) in India.

Acknowledgments The authors thank the INSPIRE fellowship, DST, India for the financial support to carry out this study.

\section{References}

Adkar-Purushothama CR, Casati P, Quaglino F, Durante G, Bianco PA (2009) First report of a 'Candidatus Phytoplasma asteris' -related strain associated with a yellows disease of black pepper (Piper nigrum) in India. Plant Pathol 58:789

Baiswar P, Arocha Y, Chandra S, Ngachan SV (2010) First report of 'Candidatus Phytoplasma asteris' associated with witches'-broom of Crotalaria tetragona in India. Plant Pathol 59:397

Doi M, Tetranaka M, Yora K, Asuyama H (1967) Mycoplasma or PLTgroup like organism found in the phloem elements of plants infected with mulberry dwarf, potato witches'broom, aster yellow, or paulownias witches' broom. Ann Phytopathol Soc Jpn 33:259-266

Gundersen DE, Lee IM (1996) Ultrasensitive detection of phytoplasma by nested PCR using two universal primer pairs. Phytopathol Mediterr 35:144-157
Hibino H, Jonson GB, Sta Cruz FC (1987) Association of mycoplasmalike organisms with rice orange leaf in the Philippines. Plant Dis 71: 792-794

IRPCM (2004) 'Candidatus Phytoplasma', a taxon for the wall-less, nonhelical prokaryotes that colonize plant phloem and insects. Int J Syst Evol Microbiol 54:1243-1255

Jung HY, Sawayanagi T, Kakizawa S, Nishigawa H, Miyata S, Oshima K, Ugaki M (2002) 'Candidatus Phytoplasma castaneae', a novel phytoplasma taxon associated with chestnut witches' broom disease. Int J Syst Evol Microbiol 52:1543-1549

Khan MS, Raj SK (2006) First report of molecular detection of an Aster yellows phytoplasma isolate infecting chilli (Capsicum annuum) in India. Plant Pathol 55:822

Khan MS, Raj SK, Snehi SK (2007) First report of molecular identification of 'Candidatus Phytoplasma asteris' affecting Sesame (Sesamum indicum) cultivation in India. J Plant Pathol 89: 291-295

Lee IM, Hammond RW, Davis RE, Gundersen DE (1993) Universal amplification and analysis of pathogen 16S rDNA for classification and identification of mycoplasmalike organisms. Phytopathology 83:834-842

Lee IM, Davis RE, Gundersen DE (2000) Phytoplasma: phytopathogenic mollicutes. Annu Rev Microbiol 54:221-255

Lee IM, Gundersen-Rindal DE, Davis RE, Bottner KD, Marcone C, Seemüller E (2004) 'Candidatus Phytoplasma asteris', a novel phytoplasma taxon associated with aster yellows and related disease. Int J Syst Evol Microbiol 54:1037-1048

Nakashima K, Kato S, Iwanami S, Murata N (1993) DNA probes reveal relatedness of rice yellow dwarf mycoplasmalike organisms (MLOs) and distinguish them from other MLOs. Appl Environ Microbiol 59:1206-1212

Raj SK, Khan MS, Snehi SK, Srivastava S, Singh HB (2006) 'Candidatus Phytoplasma asteris' isolate associated with a little leaf disease of pigeon pea in India. Plant Pathol 55:823

Raj SK, Khan MS, Kumar S (2007) Molecular identification of 'Candidatus Phytoplasma asteris' associated with little leaf disease of Chrysanthemum morifolium. Aust Plant Dis Notes 2:21-22

Saitou N, Nei M (1987) The neighbor-joining method: a new method for reconstructing phylogenetic trees. Mol Biol Evol 4:406-425

Tamura K, Peterson D, Peterson N, Stecher G, Nei M, Kumar S (2011) MEGA5: molecular evolutionary genetics analysis using maximum likelihood, evolutionary distance and maximum parsimony methods. Mol Biol Evol 28:2731-2739

Thompson JD, Higgins DG, Gibson TJ (1994) Clustal W: improving the sensitivity of progressive multiple sequence alignment through sequence weighting, position-specific gap penalties and weight matrix choice. Nucleic Acids Res 22:4673-4680

Warokka JS, Jones P, Dickinson MJ (2006) Detection of phytoplasmas associated with Kalimantan wilt disease of coconut by the polymerase chain reaction. J Littri 12:154-160

Weintraub PG, Beanland L (2006) Insect vectors of phytoplasmas. Annu Rev Entomol 51:91-111 